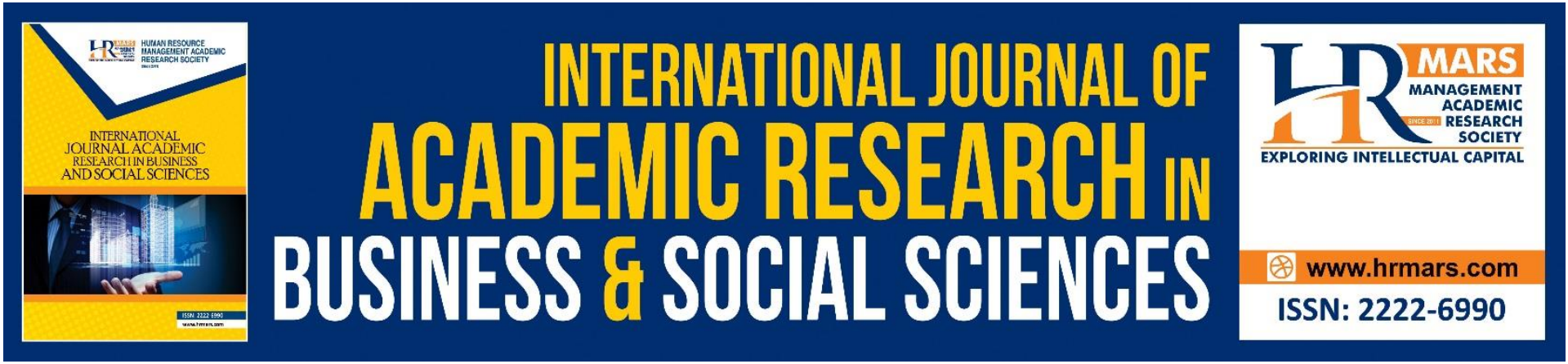

\title{
Understanding State Government-Linked Companies' Service Delivery System Successful Performance from Employees' Insights
}

Shamsul Baharin Saihani, Janiffa Saidon and Wan Edura Wan Rashid

To Link this Article: http://dx.doi.org/10.6007/IJARBSS/v11-i9/11256

DOI:10.6007/IJARBSS/v11-i9/11256

Received: 27 July 2021, Revised: 29 August 2021, Accepted: 11 September 2021

Published Online: 24 September 2021

In-Text Citation: (Saihani et al., 2021)

To Cite this Article: Saihani, S. B., Saidon, J., \& Rashid, W. E. W. (2021). Understanding State GovernmentLinked Companies' Service Delivery System Successful Performance from Employees' Insights. International Journal of Academic Research in Business and Social Sciences, 11(9), 1832-1843.

Copyright: (c) 2021 The Author(s)

Published by Human Resource Management Academic Research Society (www.hrmars.com)

This article is published under the Creative Commons Attribution (CC BY 4.0) license. Anyone may reproduce, distribute, translate and create derivative works of this article (for both commercial and non-commercial purposes), subject to full attribution to the original publication and authors. The full terms of this license may be seen at: http://creativecommons.org/licences/by/4.0/legalcode

Vol. 11, No. 9, 2021, Pg. 1832 - 1843

http://hrmars.com/index.php/pages/detail/IJARBSS

Full Terms \& Conditions of access and use can be found at http://hrmars.com/index.php/pages/detail/publication-ethics 


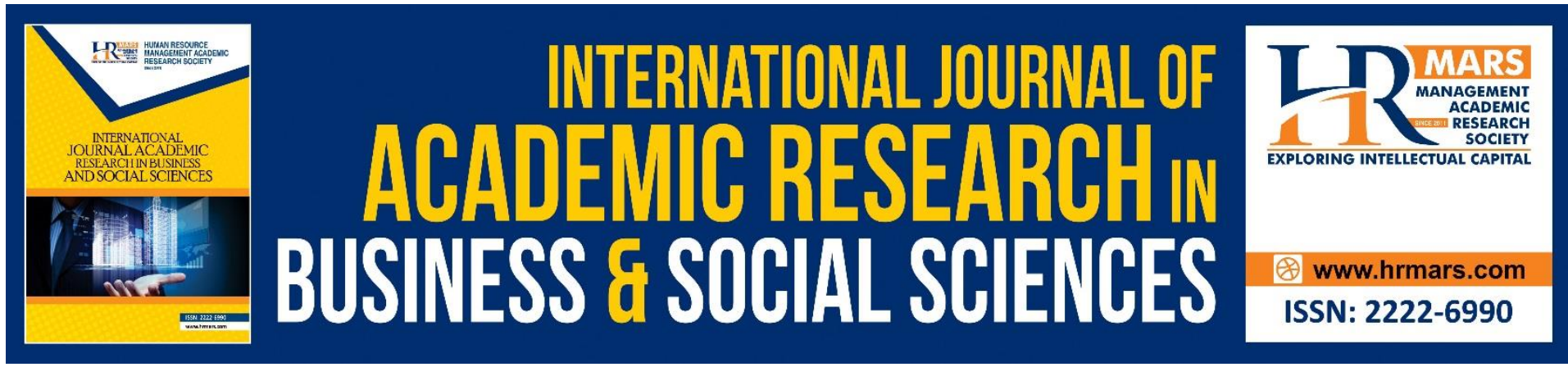

\title{
Understanding State Government-Linked Companies' Service Delivery System Successful Performance from Employees' Insights
}

\section{Shamsul Baharin Saihani ${ }^{1}$, Janiffa Saidon ${ }^{2}$ and Wan Edura Wan Rashid ${ }^{3}$}

${ }^{1}$ Institute of Business Excellence (IBE), Faculty of Business and Management, Universiti Teknologi MARA (UiTM), 40450 Shah Alam, Selangor, Malaysia, ${ }^{2}$ Faculty of Business and Management, Universiti Teknologi MARA (UiTM) Cawangan Selangor, 42300 Puncak Alam,

Selangor, Malaysia, ${ }^{3}$ Institute of Business Excellence (IBE), Faculty of Business and Management, Universiti Teknologi MARA (UiTM), 40450 Shah Alam, Selangor, Malaysia

Email: shams887@uitm.edu.my, janiffa@uitm.edu.my,wanedura@uitm.edu.my

\begin{abstract}
It is inevitable for state government-linked companies (SGLCs) or state-owned enterprises (SOEs) nowadays to respond ingeniously to many business trials and tribulations. Since these companies faced intense challenges in a very dynamic business environment, this research intends to offer recommendations to address them. Essentially, this exploratory research reviewed the literature relevant to the topic and identified the research gaps to formulate two research propositions for testing this research. The data were collected using in-depth interviews from 19 head of departments in 19 state government-linked companies. The findings indicate several emerging themes such as company policies, leadership, process improvements, consultative attitudes and community engagement are important efforts to heed for improvement in the service delivery system. These findings are useful to trigger other SGLCs and SOEs into achieving successful performance on the service delivery system by paying attention to the provided information.
\end{abstract}

Keywords: State-Government-Linked Companies, Service Delivery System, Successful Performance.

\section{Introduction}

The Covid-19 pandemic has forced governments to take various measures to prevent its spread including closing borders and quarantine measures against the virus have become mandatory measures for the general populations. Moreover, physical distancing has been introduced as a recommended social behavior (Nicola et al., 2020). As a result of the Covid19 pandemic's economic effects, many businesses, particularly those in the service industry, are suffering significant levels of economic instability, and some have chosen to lay off employees due to a lack of financial resources to pay wages (Pak et al., 2020). Staying resilient in business is no longer an option as it is a must now for companies to be innovative to remain 
competitive. This situation has also affected the state government-linked companies (SGLCs) or state-owned enterprises (SOEs) into providing an effective service delivery system.

Government-linked companies (GLCs) essentially must fulfill a dual mission such as to survive in a more liberalised business environment with new participants and competitors and to successfully fulfill its social obligations (Thompson et al., 2007). Tan (2008) further asserts that good governance, knowledge resource development, incorporating community social responsibility, effective leadership and underlining corporate culture as critical factors to achieving successful performance. Despite their corporate status, GLCs are unique commercial organisations because they still have to strike a balance with the public policy objectives (Powell, 1987). GLCs can be entirely or partially owned by the government and engage in a wide range of economic and non-economic activities in various fields. Since governments might own conventional stock without influencing the activities of corporate firms, it is difficult to identify categorically what level of state ownership would qualify an entity to be labelled a GLC (Vining \& Boardman, 1992). For instance, GLCs are classified as 'State-Owned Enterprises' (Kim \& Ali, 2017), which are either government-owned or government-controlled economic enterprises that generate a significant portion of their revenue through the sale of products and services. As a result, the term "government-linked companies" (GLCs) is used interchangeably in this study to refer to State Government-Linked Companies (SGLCS) and State-Owned Enterprises (SOEs).

The importance of state or government ownership in Asian countries cannot be ignored, especially in terms of market value after the Asian economic crisis (La Porta et al., 1999). GLC plays an important role in accelerating Malaysia's economic growth. Government-linked company (GLC) is undoubtedly an important part of the socio-economic development of a country, but even with government participation, its effectiveness is questionable (Razak et al., 2011).

In service systems, most frameworks do not account for the many processes or channels that produce the same type of service outcomes (Tinnilae \& Vepsaelaeinen, 1995). The frequently complicated process-structure integral to service delivery systems (Larsson \& Bowen, 1989) is largely disregarded. Service operations research, consistent with Slack et al. (2004), has been in favour of business-to-consumer services. Lee (2017) further concludes that a standardised and consistent way for describing service performance that can depict the many communication channels in a service delivery process is needed. Instead of focusing on the interconnected nature of the numerous channels of service delivery, research has focused on the features of individual service processes rather than the integrated set of processes embedded into the delivery system as a whole.

One of the Unified Services Theory (UST) main assertions is that the process design dimensions found in service frameworks are directly tied to a classification of customer inputs or the treatment of customer inputs (Sampson \& Froehle, 2006). The UST can be traced back to Lovelock's (1983) classification scheme, which categorises services based on the nature of the service act. In addition, the UST focuses on the service system's transformation (valueadding) process. This marks a significant shift in service design research, as it encourages scholars to consider how inputs are converted, a crucial issue in operations management (Johnston \& Clark, 2005). 
Essentially, service delivery systems encompassed of the structure (facilities, equipment, etc.), infrastructure (job design, skills, etc.), and processes for delivering a service (Goldstein et al., 2002). The architecture of a service delivery system involved three strategic design choices: structural, infrastructural, and integrative (Roth \& Menor, 2003). In structural choices, the layout of facilities, the usage of technologies and equipment, and capacity management are all factors to consider. People, policies, procedures, processes, and performance systems are among the infrastructural choices, which pertain to the function of human resources in the service delivery system. External integration of the company's service delivery system with suppliers and customers, internal integration of structural, infrastructural and functional areas within the company, adaptive mechanisms such as intellectual capital, system knowledge, and learning are all instances of integration choices.

Meyer (2005) claims that measuring a company success is difficult. Despite these reservations, research in this area is thriving. Therefore, cross-sectional self-report investigations are favoured in this type of study. When only self-reported data is presented, Chandler and Hanks (1993) evaluate three methods for measuring success that include assessing company performance in broadly defined classifications such as expectations, evaluating subjective measures of satisfaction with overall company performance and assessing subjective measures of performance in comparison to competitors.

As the effectiveness and efficiency of service delivery among GLCs has been the priority of federal and state government of Malaysia to achieve a fully developed economy status, this study primary purpose is to explore an understanding of the state government-linked companies' service delivery system successful performance from employees' insights and the secondary purpose is to provide recommendations.

This paper is divided into five sections. The section after the introduction briefly describe the problem statement and the following section discussed the methodology used in the study. Section four will discuss the key findings and the themes that have emerged from the data transcriptions. The final section concludes this paper with some recommendation.

\section{Research Problem}

In the past, the private sector was unable or unwilling to provide the required services at an affordable cost; therefore, such an important matter should not be left to the market or private interests. As a consequence, GLCs, SGLCs or SOEs were created owing to these gaps in the market. There is no doubt that these government-link companies are the backbone of the Malaysian economy, but their inability to create values vary widely according to industry, activity type and performance, different governance and accountability mechanisms (Said et al., 2020). Many elements also influence the overall performance of the service delivery system to meet the advance expectations of various stakeholders (Chang, 2014).

SGLCS or SOEs inefficiencies in service delivery system stem from unclear goals and sometimes conflicting goals. Some companies are expected to serve the entire population or reduce geographic imbalances. Other companies that promote growth, technological advancement, or job creation; through the introduction of conflicting rules and overregulation will exacerbate these problems. Furthermore, vague and inconsistent goals, such as increasing sales, eliminating imbalances and creating jobs at the same time, often involve 
ambiguous performance standards that are vulnerable to exploitation ("The problem with SOEs", 2018). In many cases, insufficient technical and managerial skills and experience lead to inefficiency in government-linked companies. For example due to the poor performance of major players such as the Malaysia Airlines system and the public's perception of GLC in Malaysia has been tarnished (Lau \& Tong, 2008). On contrary, most studies show that government-funded GLCs in Singapore are more productive than non-government-linked companies (Ang \& Ding, 2006).

\section{Methodology}

This research is designed to stimulate an understanding on the service delivery system preference to successful performance of SGLCs or SOEs employees own self-descriptions and is qualitative, exploratory, and descriptive in nature, using an interpretivist perspective. Qualitative research (Miles \& Huberman, 1994) focuses on individuals' lived experiences and is effective for uncovering fresh or additional information on a research topic that is not well understood (Creswell, 2017). Subsequently, in keeping with the qualitative research technique, a one-on-one interview with open-ended questions was conducted to collect textual data for analysis. To avoid information loss due to language barriers, the interview was conducted both in English and Malay languages and the interviewees were given the freedom of answering in English, Malay, or a combination of both as well. Each interview lasted up to 2 hours and took 1 month to complete.

Interviewees were recruited through digital communication when face-to-face interaction was limited and then an email was sent with the questions they needed to answer. The interviewees were given time and space to think on their experiences and explain them in their own words. The interview took place based on their availability that was convenient for them. The data was validated by cross-checking facts and impressions produced by the interviewer and note-taker, and the data was conducted by two people. All interview data was recorded, but during each interview, notes were collected as well, and the interview finished with the interviewer's general impressions.

However, for the purposes of this study, nineteen (19) interviews were sufficient to begin to explore the constructs after the conceptual framework had been introduced. Researchers can stop collecting data in a qualitative study once data saturation is reached (O'Leary, 2017). To reach the saturation point in qualitative research, Braun and Clarke (2013) and Fugard and Potts (2014) suggested that a minimum sample size of at least 12 respondents must be interviewed.

To assure the study's validity, all proper procedures were used to obtain the answer to the study's main question (Kumar, 2018). The data was evaluated for emerging themes and an open coding system was developed by categorising the data (O'Leary, 2017). The data was examined in two stages: (1) while the interviews were being done, and (2) after all interviews had been completed. The researchers were able to use member checks to ensure that the respondents' personal histories were accurately portrayed. At the conclusion of each interview, a summary of what was said was emailed to the interviewees as a member check. The study team also shared the emerging themes with the interviewees and solicited feedback. 
The study was kept completely private, and only the researchers were aware of who they were. The data was only used and released in aggregate form. The participants were informed that the interview was optional, and the data and findings, as well as a summary of the study, were shared. Finally, the researchers controlled the research process in a transparent manner from start to finish. This allowed the researchers to demonstrate the study's validity. Unlike quantitative research, qualitative research necessitates a lengthy administrative process to assure the "reliability" of the methodologies, documentation, and design (O'Leary, 2017).

Participants were carefully picked based on established criteria using a purposive sampling technique. The method entails identifying and selecting individuals or groups who are knowledgeable and have a strong interest (Creswell \& Plano Clark, 2011). Using professional network of contacts, the identified participants were chosen based on the following criteria such as i) working in SGLCs or SOEs; ii) working professional as head of department; iii) generational groups in workforce using works from Strauss and Howe (1991), such as baby boomers, $\mathrm{X}$, and $\mathrm{Y}$ or Millennials to understand different generation outlooks; iv) regardless of gender. Although the goal of this study was not to obtain a statistically valid sample, the researchers picked a number of relevant companies that employ a significant number of Malaysians in order to offer the study a broad scope.

\section{Findings and Discussion}

Collier and Meyer (1998) stated that the characteristics of a service delivery system are determined by the number of client channels and managerial control. The employment of new technologies in service delivery systems has a significant impact on issues relating to service process design and system structure (Hill et al., 2002). Studying the nature of client inputs to the service delivery system essentially can provide few insights into the service process design. This creates a framework that goes beyond the confines of past work, which has mostly focused on consumer presence.

As a result, a renewed conceptual framework of service delivery system for SGLCs and SOEs and its impact on successful performance have emerged as a consequence of the qualitative investigation. The following discussion will help to grasp the emergent conceptual framework. The following five categories of variables emerged as SGLCs or SOEs employees' preferred service delivery system for successful performance that include (i) company policies; (ii) leadership; (iii) process improvements; (iv) consultative attitudes; and (v) community engagement.

This section delves into each of these categories in-depth to familiarise the reader with the topic of the study. The findings include extracts from in-depth interviews to provide further facts and comprehension of the study. Table 1 illustrates the demographic profiles of the study's participants. Head of department of SGLCs or SOEs in Malaysia who have been with the company for at least a year are interviewed. 
Table 1: Demographic profiles of the participants

\begin{tabular}{clcl}
\hline Participant (P) Code & Gender & Generational Group & Industry \\
\hline P1 & Male & X & Finance and Investment \\
P2 & Female & Y & Food and Beverages \\
P3 & Male & X & Hospitality \\
P4 & Male & X & Property \\
P5 & Male & Baby boomers & Manufacturing \\
P6 & Male & Baby boomers & Utility \\
P7 & Male & X & Printing \\
P8 & Male & X & Training and education \\
P9 & Male & Baby boomers & Finance and Investment \\
P10 & Male & Y & Hospitality \\
P11 & Male & X & Hospitality \\
P12 & Male & Baby boomers & Property \\
P13 & Male & X & Manufacturing \\
P14 & Female & Y & Hospitality \\
P15 & Male & Baby boomers & Manufacturing \\
P16 & Male & $X$ & Plantation \\
P17 & Male & $X$ & Plantation \\
P18 & Male & $X$ & Property \\
P19 & Male & Y & Food and Beverages \\
\hline
\end{tabular}

\section{Theme 1: Company Policies}

Several SGLCS or SOES poor performance can be traced back to operational coordination inefficiencies caused by a lack of change management strategies based on ongoing reviews of business procedures and processes as highlighted by participants such as P1, P5, P6, P15, P16, and P18. A proper business legal framework separating the functions of public service and private service is also required for SGLCs or SOEs to function efficiently as stated by P1, P8 and P9. Furthermore, participants P3, P4, P8, P9, P13, P14, P16 and P17 reiterate that the measures put in place should aim to improve the business climate and boost the economy's competitiveness which is similarly supported by the study of Rondinelli (2008). P7, P10, P11, $\mathrm{P} 12$ and $\mathrm{P} 19$ indicate that with the correct policies and relevant institutional framework by coordinating present organisations, departments and various agencies, the existing SGLCs or SOEs should be able to foster high levels of service delivery system outcomes such as information transparency and innovativeness. These outputs assert Gautam (2020) conclusions that maintenance of coordination is essential to deliver an effective public service delivery. Additionally, findings from the generational group are quite mixed. After synthesising the participants' inputs, it was evident that clear policies are needed and can only be achieved through good coordination.

\section{Theme 2: Leadership}

Across all of the emerging themes, the interviewees' responses on the critical role of leadership in the successful performance of service delivery systems are consistent. A leader, according to the majority of the participants, must have the competency, skills, and knowledge to do the job. Interestingly, both female participants (P2 and P14) agree with Ghasemy et al. (2018) findings that the leader-employee relationship can improve performance, especially if leadership effectiveness is ensured within the company. 
Participants such as P5, P7, P8, P16, and P17 instead have similar perspectives on how knowledge sharing might help leaders promote successful performance. Considering that the organisation requires both leader and knowledge to improve the effectiveness of the service delivery system, knowledge sharing largely leads to the generation of information within the company. Good leadership inspires a desire for high performance work culture among employees particularly when transparent performance appraisal is in place (Harun et al., 2021). This increases employee commitment, motivation, and intention to stay.

\section{Theme 3: Process Improvements}

Given the impact clients can have on the outcomes of the service delivery, it can be quite challenging to provide service that is valued by the people who get it. As a result, creating sustainable service delivery, which is a process that lasts over time by maximising existing resources while providing sufficient benefit to clients, can be difficult for these SGLCs or SOEs. According to participants P3, P4, P11 and P13, having standardise continuous improvement framework will greatly affect the outcomes of the service delivery. Majority of the participants from generation $X$ are also supportive to the general idea on underlining the importance of understanding the complexities of many stakeholders' service delivery requirements and improvement on the service design processes must take into consideration of giving them with a variety of channels and interfaces via a demand-driven model. Thus, the framework would aid in breaking down the interdepartmental silos that have become a stumbling block in improving processes. Participants P1, P9, P16 and P17 moreover posit that technology and process innovations for SGLCs or SOEs process improvement are frequently grafted onto old bureaucracies, locking in expensive integration costs and risking producing areas of effective service delivery rather than facilitating an integrated approach across the board. Fei et al. (2019) indicate that failure by the organisation to fulfil specific resources' obligations to the employees such as limited technological support would result in less enthusiasm for quality improvement. Hence, alignment of service objectives of process improvements with service delivery system is needed (Silvestro \& Silvestro, 2003).

\section{Theme 4: Consultative Attitudes}

GLCs at all levels have expressed an interest in better-designed programmes and consultation processes to better respond to and serve individuals and communities (Bourgon, 2011). In the consultative attitudes model, a wide range of players are involved, and the focus is less on customers and more on meeting the needs of many stakeholders (Lim et al., 2007). Three out of four participants from generation $\mathrm{Y}$ agree that adopting a consultative mindset will help to improve the service delivery system's quality level. Rather than focusing on providing more efficient service delivery to clients, as the managerial model emphasises, the SGLCs or SOEs goal is to make better policy decisions with stakeholders' involvement (Anttiroiko, 2010). Furthermore, participants P4, P8, P14 and P19 feel that technology used in the consultative attitudes enable two-way communication and can help in improving SGLCs or SOEs public and business policies aimed at stakeholders' feedback.

\section{Theme 5: Community Engagement}

The hope that better service would lead to an increase community trust in SGLCs or SOEs fueled by government investments in enhancing service delivery remains a challenge. For instance, local governments are experimenting various types of community delivery services model involving business entities with public companies (Cepiku et al., 2016; Ferran \& Puey, 
2016). According to participants P1, P4, P5, P13, P15, P16 and P17, even if SGLCs or SOEs continue to make progress with community-oriented service delivery and engagement, there is still a need to supplement existing measurement tools with qualitative approaches by engaging their communities in a conversation about the types and mix of services and policies they want to receive. The statement is also supported by Howard (2010). Furthermore, information and communication technologies (ICTs) may prompt SGLCs or SOEs to rethink the role of government bureaucracies in delivering community programmes and developing policy (Dunleavy et al., 2006). Participants P10, P11 and P15 for example, think that by engaging community in the multifaceted design of service delivery system would minimise leakages in the associated long-term cost.

\section{Conclusions}

This study has some limitations that should be mentioned. First, because this study is limited by the questions asked during the interviews, certain themes will be missing from the data analysis. Furthermore, the demography profile uses in the study is also constrained by the inadequate number of industries, managerial roles and gender. Therefore, it is hard to derive a representative conclusion. Finally, the interviews are conducted at a firm level and only from the perspectives of present employees. Future study should take into consideration of other stakeholder's insights such as from the communities and customers. The conceptual framework underscores in this study however, is congruent with the previous work of Roth and Menor (2003) and Goldstein et al. (2002), who produced service delivery system definitions ranging from the firm's strategic environment to operational features and design principles. The findings also supported Tan (2008) and Chang (2014) position that many factors such as good governance, knowledge resource development, incorporating community social responsibility and effective leadership influence the overall performance of the service delivery system in terms of meeting the expectations of diverse stakeholders. This last point emphasises the importance of thoroughly examining the cumulative effects of numerous service delivery strategies from the community's perspective, as well as pursuing service integration in more robust, consultative, and bottom-up fashion. As a result, service delivery system design entails not only gauging public satisfaction with current encounters, but also engaging them in a discussion about what kinds of services are most needed, and how the selection and crafting of delivery mechanisms can improve community prospects for innovation and growth. Such consultative attitudes and community-based approach that stresses on leadership, company policies, and process improvements highlighted in the study are particularly imperative for formulating successful multi-channel SGLCs or SOEs service delivery system strategies to serve the stakeholders interest and collective trade-offs between values such as efficiency, employment and equity.

\section{References}

Ang, J. S., \& Ding, D. K. (2006). Government ownership and the performance of governmentlinked companies: The case of Singapore. Journal of Multinational Financial Management, 16(1), 64-88.

Anttiroiko, A. V. (2010). Innovation in democratic e-governance: Benefitting from Web 2.0 applications in the public sector. International Journal of Electronic Government Research (IJEGR), 6(2), 18-36.

Bourgon, J. (2011). A new synthesis of public administration: Serving in the 21st century (Vol. 81). McGill-Queen's Press-MQUP. 
Braun, V., \& Clarke, V. (2013). Successful qualitative research: A practical guide for beginners. Sage.

Cepiku, D., Mussari, R., \& Giordano, F. (2016). Local governments managing austerity: Approaches, determinants and impact. Public Administration, 94(1), 223-243.

Chandler, G. N., \& Hanks, S. H. (1993). Measuring the performance of emerging businesses: A validation study. Journal of Business Venturing, 8(5): 391-408.

Chang, T. H. (2014). Fuzzy VIKOR method: A case study of the hospital service evaluation in Taiwan. Information Sciences, 271, 196-212.

Collier, D. A., \& Meyer, S. M. (1998). A service positioning matrix. International Journal of Operations \& Production Management.

Creswell, J. W., \& Creswell, J. D. (2017). Research design: Qualitative, quantitative, and mixed methods approaches. Sage publications.

Creswell, J. W., \& Clark, P. V. L. (2011). Designing and conducting mixed methods research (2nd ed.). Thousand Oaks, CA: Sage

Dunleavy, P., Margetts, H., Bastow, S., \& Tinkler, J. (2006). New public management is deadlong live digital-era governance. Journal of public administration research and theory, 16(3), 467-494.

Fei, W., Selvanathan, M., Supramaniam, M., Suppramaniam, S., \& Xu, Y. (2019). Quality Service Delivery Systems among Government Agencies in Malaysia. International Journal of Innovation, Creativity and Change, 5(2), 995-1020.

Ferran, J. M., \& Puey, E. P. (2016). Delivery of Municipal Services in Spain: an uncertain picture. In Public and social services in Europe (pp. 119-134). Palgrave Macmillan, London.

Fugard, A. J., \& Potts, H. W. (2015). Supporting thinking on sample sizes for thematic analyses: a quantitative tool. International Journal of Social Research Methodology, 18(6), 669684.

Gautam, A. (2020). Role of Coordination in Effective Public Service Delivery System. Journal of Public Administration and Governance, 10(3), 158171-158171.

Ghasemy, M., Hussin, S. B., Abdul Razak, A. Z. B., Maah, M. J. B., \& Ghavifekr, S. (2018). Determining the key capacities of effective leaders in Malaysian public and private focused universities. Sage Open, 8(4), 2158244018807620.

Goldstein, S. M., Johnston, R., Duffy, J., \& Rao, J. (2002). The service concept: the missing link in service design research? Journal of Operations Management, 20(2), 121-134.

Harun, S., Shahid, S. A. M., A. K., Othman, M. K. B. A., Rahman, \& Gumbri, D. T. (2021). The Influence of HRM Practices on Employee Behavioural Intentions: Do Generational Differences Matter? International Journal of Academic Research in Business and Social Sciences, 11(4), 284-294.

Hill, A. V., Collier, D. A., Froehle, C. M., Goodale, J. C., Metters, R. D., \& Verma, R. (2002). Research opportunities in service process design. Journal of Operations Management, 20(2), 189-202.

Howard, C. (2010). Are we being served? A critical perspective on Canada's citizens first satisfaction surveys. International Review of Administrative Sciences, 76(1), 65-83.

Johnston, R., \& Clark, G. (2008). Service operations management: improving service delivery. Pearson Education.

Kim, C. J., \& Ali, Z. (2017). Efficient management of state-owned enterprises: challenges and opportunities. Asian Development Bank Institute.

Kumar, R. (2018). Research methodology: A step-by-step guide for beginners. Sage. 
Lau, Y. W., \& Tong, C. Q. (2008). Are Malaysian government-linked companies (GLCs) creating value. International Applied Economics and Management Letters, 1(1), 9-12.

Larsson, R., \& Bowen, D. E. (1989). Organization and customer: managing design and coordination of services. Academy of Management Review, 14(2), 213-233.

La Porta, R., Lopez-de-Silanes, F., \& Shleifer, A. (1999). Corporate ownership around the world. The Journal of Finance, 54(2), 471-517.

Lee, E. (2017). Describing Service Performances: What Are the Challenges? In Advances in The Human Side of Service Engineering (pp. 269-274). Springer, Cham.

Lim, E. T., Tan, C. W., \& Pan, S. L. (2007). E-Government implementation: Balancing collaboration and control in stakeholder management. International Journal of Electronic Government Research (IJEGR), 3(2), 1-28.

Lovelock, C. H. (1983). Classifying services to gain strategic marketing insights. Journal of Marketing, 47(3), 9-20.

Meyer, M. (2005). Can performance studies create actionable knowledge if we can't measure the performance of the firm? Journal of Management Inquiry, Vol. 14 No. 3, pp. 28791.

Miles, M. B., \& Huberman, A. M. (1994). Qualitative data analysis: An expanded sourcebook. Sage.

Nicola, M., O'Neill, N., Sohrabi, C., Khan, M., Agha, M., \& Agha, R. (2020). Evidence based management guideline for the COVID-19 pandemic-Review article. International Journal of Surgery, 77, 206-216.

O'leary, Z. (2017). The essential guide to doing your research project. Sage.

Pak, A., Adegboye, O. A., Adekunle, A. I., Rahman, K. M., McBryde, E. S., \& Eisen, D. P. (2020). Economic consequences of the COVID-19 outbreak: the need for epidemic preparedness. Frontiers in public health, 8, 241.

Powell, V. (1987). Improving public enterprise performance: concepts and techniques (No. 22). International Labour Organization.

Razak, N. H. A., Ahmad, R., \& Joher, H. A. (2011). Does government linked companies (GLCs) perform better than non-GLCs? Evidence from Malaysian listed companies. Journal of Applied Finance \& Banking, 1(1), 213-240.

Rondinelli, D. A. (2008). Can public enterprises contribute to development? A critical assessment and alternatives for management improvement. In Public Enterprises: Unresolved Challenges and New Opportunities. Publication based on the Expert Group Meeting on Re-inventing Public Enterprise and their Management. United Nations.

Roth, A. V., \& Menor, L. J. (2003). Insights into service operations management: a research agenda. Production and Operations Management, 12(2), 145-164.

Said, J., Alam, M. M., Radzi, N. B. M., \& Rosli, M. H. (2020). Impacts of accountability, integrity, and internal control on organisational value creation: evidence from Malaysian government linked companies. International Journal of Business Governance and Ethics, 14(2), 206-223.

Sampson, S. E., \& Froehle, C. M. (2006). Foundations and implications of a proposed unified services theory. Production and Operations Management, 15(2), 329-343.

Silvestro, R., \& Silvestro, C. (2003). New service design in the NHS: an evaluation of the strategic alignment of NHS Direct. International Journal of Operations \& Production Management.

Slack, N., Chambers, S., \& Johnston, R. (2010). Operations Management. Pearson education. Sundram, J. K. (2018). The problem with SOEs. NST Online. 
https://www.nst.com.my/opinion/columnists/2018/08/402253/problem-soes

Strauss, W., \& Howe, N. (1991). Generations: The History of America's Future, 1584-2069. New York: William Morrow.

Strickland, T., Thompson, A., \& Gamble, J. (2007). Crafting and executing strategy: Text and readings. Mcgraw Hill.

Tan, L. L. (2008). The internationalisation of Malaysian manufacturing small and medium enterprises (Doctoral dissertation, Southern Cross University).

Tinnilä, M., \& Vepsäläinen, A.P. (1995). A model for strategic repositioning of service processes. International Journal of Service Industry Management.

Vining, A. R., \& Boardman, A. E. (1992). Ownership versus competition: Efficiency in public enterprise. Public choice, 73(2), 205-239. 